\title{
ТЕХНОЛОГІЯ ТА ОБЛАДНАННЯ ДЛЯ ОЧИЩЕННЯ ДРУКАРСЬКИХ ФОРМ
}

( В. П. Котляров, д.Т.н., професор, М. Г. Ткачук, магістрант, НТУУ «КПІ», Київ, Україна

\section{Предлагается алгоритм проектирования технологической операции та конструкция лазерной технологической} установки с переменными излучателями для удаления остатков краски из ячеек печатных форм. Приводятся схемы и конструкции технологической оснастки для совершенствования технологической операции очистки.

The algorithm of technological operation planning and laser technological setting construction is offered with variable lasers for deleting of ink tailings from the printing forms. Charts and constructions of the technological rigging are pointed for perfection of technological cleaning operation.

\section{Вступ}

Виготовлені тим чи іншим способом друкарські форми, які призначені для одержання відбитку за різними методами, $€$ технологічним оснащенням операції друку з багатократним використанням, чим досягається встановлений наклад друкованої продукції. Умовою такої форми забезпечення процесу друку є збереження початкових експлуатаційних властивостей форми протягом періоду їх використання, до яких можна віднести: збереження чіткості растрової структури робочої поверхні форми, відсутність слідів механічних пошкоджень, повне видалення залишків фарби на пробільних елементах форм для високого друку, та в комірках (рисках чи лунках) форм глибокого друку. При виконанні останньої умови $є$ висока вірогідність порушення двох перших умов.
До відомих методів позбавлення форм від залишків фарби використовуються звичайні для очищення поверхонь заготовок методи [1]:

- хімічне очищення робочих поверхонь (витравлення залишків фарби);

- електрохімічне обезжирення поверхонь від бруду і плівок органічного походження [2];

- ультразвукове видалення бруду шляхом створення кавітації в рідині, в якій розміщені заготовки;

- струминна (в тому числі гідроструминна) обробка поверхні прискореними частками (піском 3 корунду, кварцу або металевим порошком - для форм із металів; гранулами із хімічних речовин, наприклад із соди - для форм із легко руйнівних матеріалів: гуми, поліуретану, капрону, цинку та пластмас); 
- очищення поверхні при її опроміненні лазерним променем [3].

Аналізуючи можливості використання наведених методів очищення в технології відновлення елементів друкарських форм, можна зробити такі висновки:

- більшість 3 них (крім лазерного очищення) потребує використання витратних матеріалів (хімічних сполучень, робочих рідин, піску та порошків), що ускладнює технологічне забезпечення операції очищення та ставить якість результатів обробки від їх властивостей;

- ці ж методи екологічно небезпечні та потребують додаткових витрат на утилізацію відпрацьованих матеріалів;

- за технологічними можливостями очищення комірок форми при утриманні наведених вище умов згадані методи можна характеризувати наступним чином:

- хімічне діяння на залишки фарби декілька її розм'якшує, але для видалення із комірок механічні засоби (щітки) неефективні внаслідок їх не співмірності 3 розмірами комірок;

- струмені із піску та гранул або «холодне кипіння» при кавітації не гарантують кероване та повне очищення форм від деяких фарб (зокрема, водних та титанових), крім того є підвищений ризик руйнування поверхні форми та її елементів, особливо, високо лінеатурних;

- при очищенні за всіма методами, включаючи лазерне опромінення, можливе пошкодження регулярного мікро- рельєфу робочої поверхні форми та зниження її якості за неоптимального технологічного регламенту виконання операції.

Підсумовуючи аналіз можливості використання методів очищення виробів загального машинобудування для очищення друкарських форм від фарби, можна визначити, що найменшими вадами характеризується очищення робочих поверхонь форм лазерним опроміненням. однак, ця операція потребує складного технологічного забезпечення - обрання режиму опромінення, устаткування та оснащення.

\section{Постановка проблеми, аналіз попередніх розробок}

Перевага технології лазерного очищення базується на загальновизнаних достоїнствах обробки лазерним променем: керованість процесом завдяки можливості багатостороннього впливу на узагальнену характеристику лазерного променя в зоні обробки - інтенсивність $I_{p}$. Це досягається зміненням енергетичних параметрів променя, його просторових характеристик (кутом розбіжності $\theta$, діаметром та розподілом потужності в перетині променя), часу опромінення та розміру зони обробки (видом та параметрами перетворюючого оптичного елементу лазерної технологічної установки (ЛТУ) - його фокусною відстанню $\mathrm{F}$ і умовами опромінення - положенням заготовки в каустиці пучка випромінювання $\Delta \mathrm{F}$ та швидкістю їх відносного переміщення V). До 
того ж, можливе створення вибіркового поглинання променистої енергії матеріалом форми та брудом (залишки фарби, окисні та жирові плівки, пил, тощо), що видаляється, відповідним вибором хвильових характеристик променя - довжини хвилі $\lambda$, тобто типу випромінювача.

Оцінюючи фактичний об'єм факторного простору, в межах якого знаходиться та шукається оптимальний технологічний регламент виконання операції очищення друкарської форми (сукупність та рівні параметрів пучка випромінювання та умов опромінення), та, враховуючи особливості його реалізації на сучасних Лту, необхідно визнати складність та неординарність завдання одного із складових технологічного забезпечення операції - визначення режиму її виконання [4].

Другою проблемою для технолога $€$ створення (обрання, модернізація) технологічної установки для реалізації розробленої операції за умови досягнення задекларованих переваг лазерного очищення форм для друку: легке пристосування до змінних технологічних обставин (матеріалу форми та типу фарби), повне видалення бруду, незайманість робочих елементів, включаючи стан їх поверхні та висока продуктивність операції. Очевидно, що при компоновці лТу із покупних (серійних) вузлів (лазера, технологічного модуля та його складових (оптичної системи, механізмів переміщення та обертання заготовки або лазерного променя, засобів контролю та автоматизації діяння складових ЛТУ) важко витримати більшість визначених технологічних вимог, якщо не передбачити застосування додаткового технологічного оснащення серійних вузлів сканерами, модуляторами, трансфокаторами тощо [5].

Таким чином, для успішного досягнення мети - технологічного забезпечення застосування лазерної технології в операціях очищення друкарських форм необхідно виконати наступні завдання:

- уточнити методику вибору режиму лазерного опромінення для обраного механізму очищення, найбільш ефективного для окремих технологічних випадків;

- визначити склад та розробити компоновку Лту для виконання технологічної операції лазерного очищення циліндрових форм, забезпечуючи необхідний комплекс робочих переміщень;

- розробити робочі креслення лТУ та технологічного оснащення для створення можливостей її оперативного переналагодження для різних технологічних випадків.

\section{Результати проведених досліджень}

Порядок визначення режиму лазерної обробки в операціях очищення поверхні форми залежить від обраного механізму видалення бруду, в результаті реалізації якого останній повинен відділитися від поверхні виробу та надбати достатньої кількості кінетичної енергії для упевнено- 
го видалення за межі зони очищення (опромінення). Застосовуються два типи енергетичного впливу на бруд: випаровування та термомеханічне його самовидалення. Кожний з них базується на тепловій дії лазерного променя на елементи бруду або поверхню виробу, що очищають [3].

1. Очищення поверхні виробу випаровуванням бруду

Видалення залишків фарби їх абляцією може реалізовуватися внаслідок організації вищого рівня поглинання променистої енергії складовими бруду ніж матеріалом виробу, що очищають. Якщо вони контрастно відрізняються оптичними властивостями (коефіцієнтом поглинання A, шорсткістю поверхні та електропровідністю), то це завдання вирішується при визначенні типу випромінювача для лту. 3 позиції ефективності перетворення променистої енергії в теплову у разі металевих друкарських форм, наприклад, із цинку, які потрібно очищувати від поліграфічних фарб на основі органічних смол, найбільш придатним може вважатися $\mathrm{CO}_{2}$ лазер 3 довжиною хвилі $\lambda=10,6$ мкм $\left(A_{Z n} \leq 0,1\right.$; $\left.A_{\text {фар }} \geq 0,9\right)$ для створення вибіркового поглинання фарбою та формою. Для підвищення ефективності механізму видалення бруду випаровуванням необхідно використання об'ємного характеру його випаровування, обираючи лазер Лту, випромінювання якого глибоко проникає в бруд, тобто має показник поглинання $\alpha$ (відповідно до закону Бугера-Ламберта-Бе- ра [6]) суттєво менший, ніж для матеріалу форми. Наприклад, для очищення металевої форми $(Z n)$ від залишків фарби є також можливим використання твердотільних лазерів з випромінюванням довжиною хвилі 1,06 мкм (YAG: $\mathrm{Nd}^{+3}$, дискових лазерів) або 1,07 мкм (волоконний лазер на $\mathrm{Yb}^{+3}$ ), для яких показник поглинання $\alpha_{\mathrm{Zn}}=$ $=10^{5}-10^{6} \mathrm{~cm}^{-1}$, та $\alpha_{\text {фар }}=$ $=10^{1}-10^{2} \mathrm{~cm}^{-1}$. В разі очищення анілоксових форм, поверхню яких вкрито керамікою, використання твердотільних лазерів при $\left(\alpha_{\text {кер }}=30 \mathrm{~cm}^{-1}\right.$ може привести до руйнування елементів форми, тому переважно використання випромінювання $\mathrm{CO}_{2}$ лазера ( $\lambda=10,6$ мкм) з показником поглинання $\left(\alpha_{\text {кер }}=10^{4} \mathrm{~cm}^{-1}\right.$, що гарантує обраний вид сполучення видів теплових джерел у виробі та в шарі бруду.

Додатковим шляхом збереження якості елементів форми $€$ скорочення теплового впливу на них шляхом обмеження рівня інтенсивності випромінювання на поверхні виробу та тривалості опромінення. Тому операції очищення потребують імпульсного режиму роботи лазера, причому часові його характеристики скоріше визначаються матеріалом форми, ніж розмірними та якісними характеристиками бруду. Враховуючи діапазон змінення тривалості імпульсу випромінювання, необхідної для різних технологічних ситуацій $(\tau \in 20$ нс $\div 120$ мкс [7]), та відомі методи формування часової структури випромінювання, необхідно передбачити в 
конструкції ЛтУ відповідні засоби для можливості реалізації оптимальних технологічних регламентів.

Інший механізм видалення бруду шляхом випаровування контактного з ним прошарку матеріалу заготовки, який застосовується для очищення поверхонь металевих заготовок, не може застосовуватися для очищення друкарських форм, тому що це може викликати змінення структури рельєфу поверхні елементів форми, тобто викликати втрату її працездатності.

Технологічна схема операції видалення бруду (рис. 1) базується на тезі переваги застосування випромінювання такої довжини хвилі, яке добре поглинається в шарі бруду із утворенням об'ємного теплового джерела, що гарантує вибухо- подібне руйнування шару в режимі самовидалення 3 комірок форми, але погано взаємодіє з матеріалом заготовки (форми). В цьому разі якісне очищення останніх гарантується виключенням із механізму руйнування бруду плавлення його складових механізмом теплопровідності. Умовою створення об'ємного джерела $\epsilon \delta>\sqrt{\text { at }}(\delta-$ глибина проникнення випромінювання в матеріал $\delta=1 / \alpha$; a - його температуропровідність; $\mathrm{t}$ - тривалість опромінення). Якщо також виконується умова $r_{0}=d_{0} / 2>>\sqrt{a t}$, то можна знехтувати і бічною теплопровідністю.

Для випромінювання $\mathrm{CO}_{2}$ лазера, лінійний показник поглинання якого в органічній фарбі $\alpha=10^{2} \mathrm{~cm}^{-1}$, а глибина проник-

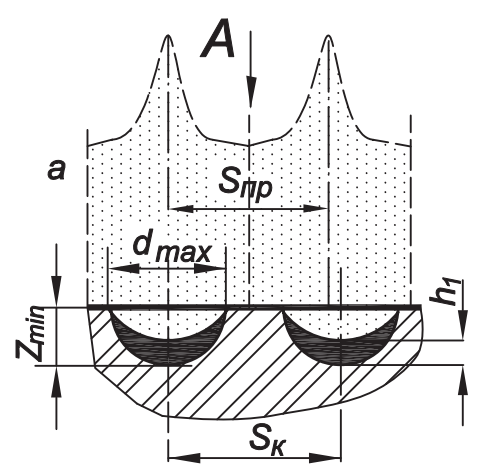

Buд A

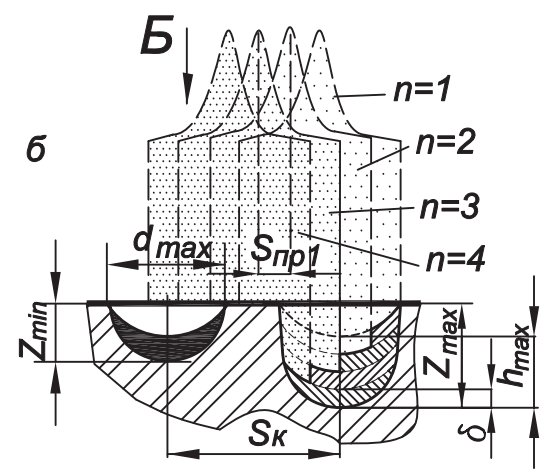

Bud 5
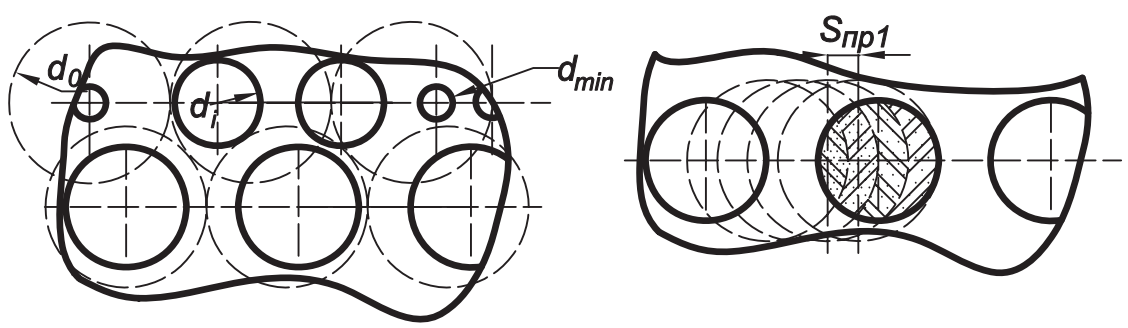

Рис. 1. Схема опромінення поверхні форми для видалення бруду (а - одним імпульсом, б - багатьма імпульсами) 
нення ( $\delta=0,01$ см, об'ємне теплове джерело створиться, якщо тривалість імпульсу випромінювання не буде перевищувати значення $\tau<<\mathrm{t}=\delta^{2} / \mathrm{a}$. Для сухих залишків фарби в комірках, для яких можна прийняти теплофізичні константи, як для органічного матеріалу - каніфолі (теплопровідність $\mathrm{k}=0,158 \mathrm{Bт} /\left(\mathrm{M} \cdot{ }^{\circ} \mathrm{C}\right)$; питома теплоємність $\mathrm{c}_{\mathrm{p}}=$ $=2,16 \cdot 10^{3}$ Дж/(кг $\left.{ }^{\circ} \mathrm{C}\right)$; щіль-

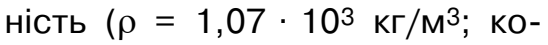
ефіцієнт температуропровідності $\left.a=6,83 \cdot 10^{-8} \mathrm{~m}^{2} / \mathrm{c}\right)$, $\mathrm{t}=0,146 \mathrm{c}, \mathrm{ar} \mathrm{r}_{0} \gg \sqrt{\mathrm{a} \tau}=1,31 \cdot 10^{-6} \mathrm{M}$ (для $\tau=2,5 \cdot 10^{-5} \mathrm{c}$ ), тобто умови об'ємності нагрівання бруду будуть виконуватися у цих обставинах.

Порядок визначення режимів обробки

Вихідні дані:

- матеріал форми (оптичні та теплофізичні властивості);

- тип фарби (оптичні та теплофізичні властивості);

- розмірні показники робочої поверхні форми (ширина b (діаметр d) та глибина найбільшої та найменшої комірки; щільність розташування елементів малюнка (лініатура растра));

- розміри циліндрової форми та її робочої поверхні.

Визначувані параметри технологічного регламенту: $\mathrm{d}_{0}$;

- діаметр зони опромінення

- інтенсивність випромінювання в зоні опромінення $\mathrm{I}_{\mathrm{p}}$;

- тривалість імпульсу випромінювання $\tau_{\mathrm{s}}$;

— імпульсна енергія $\mathrm{E}_{\mathrm{s}}$;
- частота подачі імпульсів;

- кількість імпульсів випромінювання $\mathrm{N}$ у пачці для очищення комірки з найтовщим шаром бруду;

- швидкість відносного переміщення $\mathrm{V}$ променя та форми;

- тривалість операції;

- параметри робочого об'єктиву (лінзи): тип, фокусна відстань F;

- умови опромінення: розташування форми в каустиці пучка випромінювання $\Delta \mathrm{F}$.

1. Діаметр пучка випромінювання повинен суттєво перевершувати величину $\mathrm{d}_{0}=$ $=2 r_{0}>>2,6$ мкм (для обраного сполучення матеріалу бруду та довжини хвилі випромінювання та незалежно від матеріалу форми), а також розмір попереку найбільшої комірки $\mathrm{d}_{\max }$ (рис. 1).

2. Рівень інтенсивності в зоні опромінення, необхідний для випаровування бруду в межах зони опромінення товщиною $\mathrm{h}_{1} \leq \delta$ :

$$
\mathrm{I}_{\mathrm{p}} \geq \rho \mathrm{c}\left(\mathrm{T}_{\mathrm{H}}-\mathrm{T}_{0}\right) \mathrm{h}_{1} / \mathrm{A}_{\phi} \tau,
$$

де $\mathrm{T}_{H}$ - температура нагрівання $\left(\mathrm{T}_{\mathrm{H}}>\mathrm{T}_{\mathrm{B}}\right.$ - температура випаровування); $\mathrm{T}_{0}$ - початкова температура в зоні опромінення. Для залишків органічної фарби (каніфоль) $\mathrm{T}_{\text {в }}=250^{\circ} \mathrm{C}, \mathrm{A}_{\text {фар }}=0,9$, $\mathrm{h}_{1} \approx 0,001 \mathrm{~cm}<\delta=10^{-2} \mathrm{~cm}$ (для $\lambda=10,6$ мкм) і при $\tau_{\mathrm{s}}=$ $=2,5 \cdot 10^{-5}$ с величина $\mathrm{I}_{\mathrm{p}} \approx$ $\approx 2,88 \cdot 10^{4}$ Вт/см² (створенню об'ємного джерела сприяє також відбиття від поверхні металевої форми залишків енергії в товщину бруду на його межі 3 формою). 
3. Тривалість імпульсу випромінювання обирають із умови $\tau<<\mathrm{t}=\delta^{2} / \mathrm{a}$.

4. Імпульсна енергія випромінювання:

$$
\mathrm{E}_{\mathrm{s}}=\mathrm{I}_{\mathrm{p}} \frac{\pi \mathrm{d}_{0}^{2}}{4} \tau_{\mathrm{s}} .
$$

Для наведених числових даних та при $\mathrm{d}_{0}=2 \cdot 10^{-2} \mathrm{~cm} \mathrm{-}$ $-\mathrm{E}_{\mathrm{s}}=0,22$ мДж.

5. Частота подачі імпульсів:

$$
v \leq \mathrm{P}_{\text {сер }} / \mathrm{E}_{\mathrm{s}} \text {, }
$$

де $\mathrm{P}_{\text {сер }}-$ середня потужність випромінювання $\mathrm{P}_{\text {сер }}=\mathrm{P}_{\mathrm{s}} \tau_{\mathrm{s}} \nu$. Для лазера 3 середньою потужністю випромінювання $\mathrm{P}_{\text {сер }}=$ $=10$ Вт частота $v_{p}=5$ кГц $<<v_{p}=$

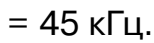

6. Якщо на дні комірки знаходиться шар бруду завтовшки $\mathrm{h}_{\max }>\delta$, то для її очищення потрібно декілька імпульсів випромінювання:

$$
\mathrm{N} \geq \mathrm{h}_{\max } / \delta .
$$

7. Швидкість переміщення пучка випромінювання (або заготовки) повинна забезпечити накладення сусідніх зон опромінення з коефіцієнтом перекриття $\mathrm{k}_{\text {п }}=\mathrm{S}_{\text {повзд }} / \mathrm{d}_{0}\left(\mathrm{~S}_{\text {повзд }}-\right.$ крок зміщення променя за період надходження імпульсів в напрямку відносного зміщення його та заготовки: для одно імпульсного видалення шару бруду $\mathrm{S}_{\text {повзд }} \leq 0,866 \mathrm{~d}_{0}$, а для обробки $\mathrm{N}$ імпульсами $\mathrm{S}_{\text {повздN }} \leq$

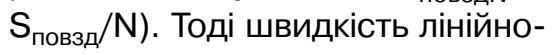
го переміщення променя:

$$
\mathrm{v}_{\text {об1 }} \leq \mathrm{S}_{\text {повзд }} \mathrm{v} .
$$

В числовому прикладі при $\mathrm{d}_{0}$ $=2 \cdot 10^{-2} \mathrm{~cm} \mathrm{~S}_{\text {повзд }} \leq 0,1732 \mathrm{Mм}$ (рис. 2), тобто $\mathrm{k}_{n}=0,866$. Приймаючи за робочу частоту подачі імпульсів $v_{p}=5$ кГц, визначимо швидкість переміщення променя (заготовки): $\mathrm{V}_{\text {об1 }}=0,86 \mathrm{~m} / \mathrm{c}$. Для реалізації такого рівня лінійної швидкості руху поверхні форми її потрібно обертати із кутовою швидкістю $\omega=2,56 \mathrm{c}^{-1}$, тобто надати валу діаметром $\mathrm{D}=100 \mathrm{Mм}$ та довжиною $\mathrm{I}=920$ мм $\mathrm{n}_{1}=165$ об/хв.

8. Тривалість операції (машинний час) очищення форми

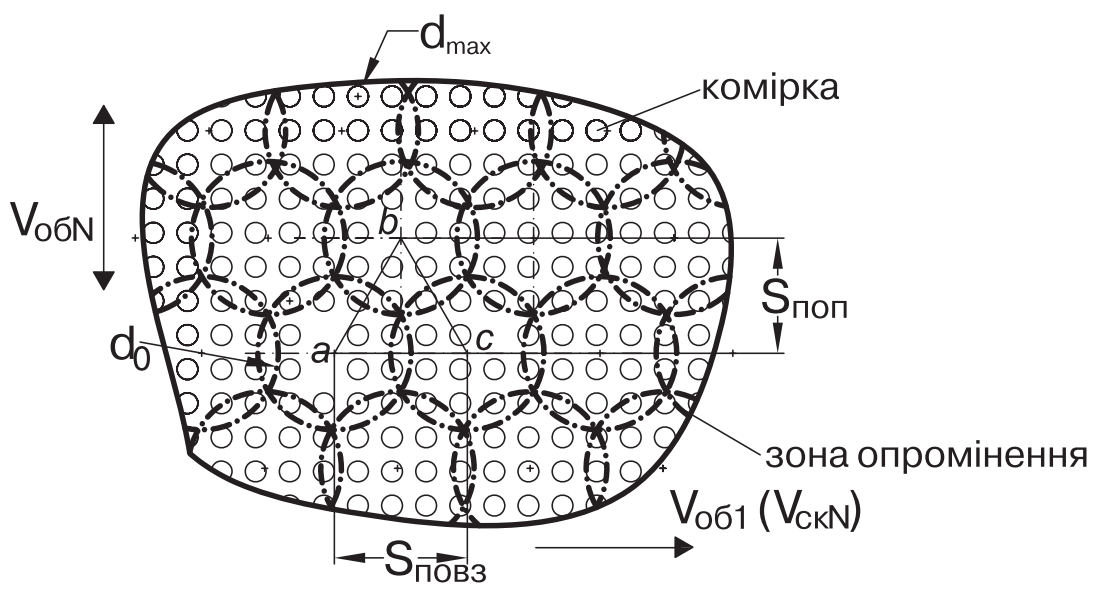

Рис. 2. Схема покриття променем поверхні форми 
робочої довжини I визначається за рівнянням:

$$
\mathrm{t}=\frac{\pi \mathrm{Dl}}{\mathrm{V}_{\text {об } 1} \mathrm{~S}_{\text {поп }}},
$$

що для $\mathrm{S}_{\text {поп }}=0,75 \mathrm{~d}_{0}=0,15 \mathrm{Mм} \mathrm{i}$ I = 500 мм складе 20,29 хв.

Таку ж тривалість операції можна одержати при меншій кутовій швидкості обертання циліндрової форми (валу) за рахунок використання швидкісного сканування променя вздовж її утворюючої. При розмаху скануючого зворотно-поступального руху променя $\left(d_{0}=0,2\right.$ мм $)$ A = 10 мм із визначеними коефіцієнтом перекриття $\mathrm{k}_{\text {п }}=\mathrm{S}_{\text {повз }} / \mathrm{d}_{0}\left(\mathrm{~S}_{\text {повз }}=0,172 \mathrm{Mм}\right)$ i частотою подачі імпульсів $v_{\mathrm{p}}=5$ кГц його тривалість складе $11,63 \cdot 10^{-3}$ с, а швидкість обертання заготовки $\mathrm{n}$ зменшиться до значення:

$$
n_{N}=\frac{V_{\text {скN }} S_{\text {поп }}}{\pi A D} 60
$$

що складе 2,46 об/хв.

9. В якості перетворюючого оптичного елементу застосовують лінзу (плоско-сферичну) із матеріалів $\mathrm{Kcl}, \mathrm{Ge}$ або $\mathrm{ZnSe}$, які прозорі для довжини хвилі $\lambda=10,6$ мкм, а деякі (ZnSe) також для випромінювання 3 видимої частини спектру. її фокусну відстань визначають із залежності $F_{p}=d_{0} / \theta$.

10. Лінза обирається із тих, що $€$ в наявності, тобто $F_{д} \neq F_{p} i$ для забезпечення обраного розміру зони опромінення при незмінному значенні кута розбіжності променя $\theta$ не- обхідна корекція умов опромінення:

$$
\begin{aligned}
& \Delta F_{\text {д }}=\frac{F_{\text {д }}}{D}\left[\theta\left(F_{p}-F_{\text {д }}\right)+\right. \\
& \left.+\left(d_{0}-F_{p} \theta\right)\right],
\end{aligned}
$$

де D - діаметр лазерного променя на рівні головної площини лінзи.

2. Очищення поверхні виробу термомеханічним руйнуванням бруду

В разі очищення поверхні форми із теплопровідного матеріалу з видаленням залишків фарби та іншого бруду випаровуванням застосування режимів опромінення з до критичним для стану матеріалу бруду рівнем інтенсивності випромінювання в промені дозволяє захистити структуру робочої поверхні від пошкодження. Низькотемпературна дія на залишки фарби та інший бруд і плівки в режимі лазерного опромінення виключає суттєвий відтік тепла за межі шару, що видаляється, тому забезпечує не тільки делікатний хід операції, але й економічний. Механізм руйнування та видалення бруду створюється при поглинанні енергії випромінювання в матеріалі бруду, перетворенні її в теплове джерело, швидкому нагріванні та термічній деформації складових бруду (розширення). Різке змінення їх розмірів та густини призводить до змінення термомеханічних властивостей, у тому числі формується ударна хвиля із розривом суцільності матеріалу та його відшаруванням від поверхні друкуючих елементів форми (рис. 3). Інерційні 


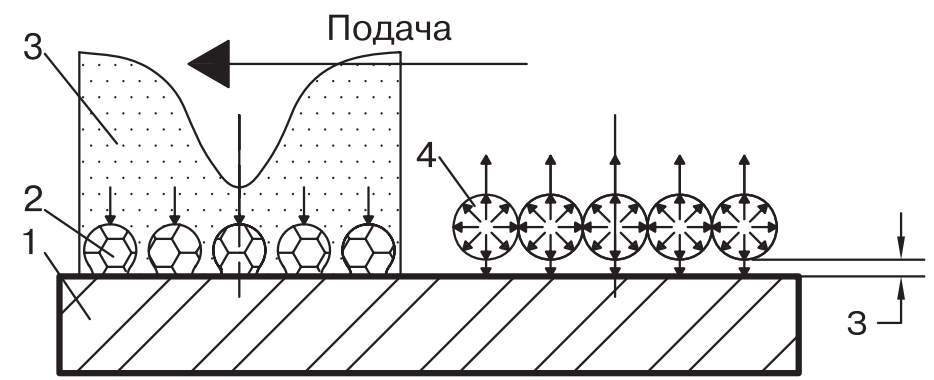

Рис. 3. Схема очищення поверхні термомеханічними силами

(1 - виріб; 2 - частки бруду; 3 - лазерний промінь; 4 - бруд в стані самовидалення)

сили, що створюються в кінці дії енергетичного імпульсу, не тільки порушують адгезію бруду до поверхні, а й забезпечують його самовидалення із комірок форми. Ерозійний факел в режимі термомеханічного очищення складається із продуктів руйнування у вигляді твердих (холодних) часток, рідких фракцій та пари, але два останніх виду створюються із супутнього залишкам фарби бруду або в результаті десорбції адсорбованих в них газів, або газифікації складових основного бруду - фарби.

За умови оптимального вибору довжини хвилі лазерного випромінювання, режиму подачі його енергії та умов опромінення цей метод пристосовано для очищення форм для друку із різних матеріалів від залишків фарби будь-якого походження (спиртових, олійних та УФфарб), причому їх висока лініатура не додає складності операції.

За низьким рівнем температури, потрібним для видалення залишків фарби $\mathrm{T}<\mathrm{T}_{\text {вип }}$ $\left(\sim 230 \div 260{ }^{\circ} \mathrm{C}\right)$, виключається можливість руйнування форм із металу, кераміки, але їх мікрорельєФ може бути спотворений при використанні гуми, поліуретану, капрону, графітвінілпласту, пластмас, в тому числі і в разі багатошарових конструкцій. Для запобігання шкідливої дії променя на неметалеві матеріали необхідно обмежити не тільки рівень його енергетичної, а й часової дії, тобто тривалість опромінення. При обранні типу лазера можливість його генерації коротких імпульсів випромінювання наносекундного діапазону має визначне значення, тому що лінійні поглинальні властивості неметалевих матеріалів суттєво не відрізняються для широкого діапазону довжин хвиль $\left(\alpha_{1,06} \approx \alpha_{10,6}=10^{2} \div 10^{3} \mathrm{~cm}^{-1}\right)$.

Для залучення механізму відокремлення фарби від поверхні елементів форми шляхом порушення її адгезії необхідно викликати теплову деформацію частки фарби в комірці з її розширенням на величину, яка визначається коефіцієнтом лінійного розширення, тобто відносним подовженням на градус нагріву $\left(\alpha_{p}=1,7 \cdot 10^{-4}\right.$ оK$^{-1}-$ для каніфолі). 
Для нагрівання залишків фарби в комірці товщиною $\mathrm{h} \leq \mathrm{Z}$ (рис. 1) до температури $\mathrm{T}_{\mathrm{H}}<\mathrm{T}_{\mathrm{B}}$ також бажаним $€$ створення об'ємного теплового джерела, але у більш короткий час для обмеження виходу тепла за межі товщини шару у матеріал форми. Це відрізняє запропонований метод від пропозиції авторів [8], які, використовуючи також режим термомеханічного видалення фарби, пропонують механізм теплопровідності для іiі наскрізного прогрівання при створенні поверхневого теплового джерела, що малореалістичне за обраною ними тривалістю імпульсу випромінювання $(\tau \leq 100 \mathrm{HC})$.

В лазерах на $\mathrm{CO}_{2}$, які генерують у імпульсному режимі, випромінювання модулюється струмом накачування активного середовища, що обмежує нижню межу тривалості імпульсів десятками мікросекунд. Використання внутрішніх модуляторів добротності резонаторів (лазерних затворів [5]) неможливо в разі відпаяних конструкцій лазерів. Тому в ЛтУ переважно застосування твердотільних лазерів на YAG: $\mathrm{Nd}^{+3}$, волокні: $\mathrm{Yb}^{+3}$ або дискових. Хоча два останні типи лазерів більш ефективні (ККД досягає 30 \%), вони характеризуються низьким рівнем кутових характеристик пучків випромінювання, особливо, волоконні, що утруднює локалізацію зони опромінення та вимагає застосування короткофокусних лінз (об'єктивів).

Порядок визначення режимів лазерного опромінення той же, що наведено вище для випар- ного механізму видалення бруду.

Умовами створення об'ємного виду поглинання заготовкою випромінювання є: тривалість імпульсу випромінювання не повинна перевищувати рівня $\tau<<\mathrm{t}=\delta^{2} \mathrm{a}$ (для каніфолі $\delta=1 / \alpha=10^{-3} \mathrm{~cm}$, тоді: $\mathrm{t}=$ $=1,46 \cdot 10^{-3}$ с). Якщо енергію проміня сконцентрувати в зону діаметром $\mathrm{d}_{0}>>2$ (at) 0,5 (для каніфолі $\mathrm{d}_{0}>>1,65$ мкм за умови $\tau \leq 1$ мкс), то можна нехтувати бічним тепловідводом.

1. Діаметр пучка випромінювання повинен суттєво перевершувати величину 1,65·10-3 мм, а також розмір попереку найбільшої комірки $\mathrm{d}_{\max }$ (рис. 1).

2. Рівень інтенсивності в зоні опромінення, необхідний для нагрівання бруду до $\mathrm{T}_{\mathrm{H}}<\mathrm{T}_{\mathrm{B}}$ в межах зони опромінення товщиною $\mathrm{h}_{1}=\delta$ :

$$
\mathrm{I}_{\mathrm{p}} \geq \rho \mathrm{c}\left(\mathrm{T}_{\mathrm{H}}-\mathrm{T}_{0}\right) \mathrm{h}_{1} / \mathrm{A}_{\phi} \tau,
$$

де $T_{H}$ - температура нагрівання $\left(\mathrm{T}_{\mathrm{H}}<\mathrm{T}_{\mathrm{B}}-\right.$ температура випаровування); $\mathrm{T}_{0}$ - початкова температура в зоні опромінення. Для залишків органічної фарби (каніфоль) $\mathrm{T}_{\mathrm{B}}=250^{\circ} \mathrm{C}, \mathrm{A}_{\text {фар }}=0,9$, $\mathrm{h}_{1} \approx 0,001 \mathrm{~cm}=\delta$ (для $\lambda=$ $=1,06$ мкм) і при $\tau_{\mathrm{s}}=10^{-6} \mathrm{c}$ рівень $\mathrm{I}_{\mathrm{p}} \approx 5,91 \cdot 10^{5} \mathrm{BT} / \mathrm{cm}^{2}$.

За такими умовами опромінення шар фарби на органічній основі завтовшки 10 мкм при його нагріванні до $\mathrm{T}_{\mathrm{H}} \approx 250{ }^{\circ} \mathrm{C}$ розшириться на $\Delta \mathrm{h}_{1}$ :

$$
\Delta \mathrm{h}_{1} \approx \alpha_{\mathrm{p}} \times \mathrm{T}_{\mathrm{H}} \times \mathrm{h}_{1}=0,425 \text { мкм, }
$$

що достатньо для відшарування фарби від поверхні форми. 
3-10. Ці пункти алгоритму виконуються за рівняннями, які наведено вище.

При цьому одержані такі чисельні дані для наведеного прикладу: $\mathrm{E}_{\mathrm{s}}=0,187$ мДж;

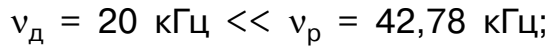
$\mathrm{V}_{\text {об1 }}=3,464 \mathrm{M} / \mathrm{c} ; \omega=11,03 \mathrm{c}^{-1}$; $\mathrm{n}=661,6$ об/хв; $\mathrm{t}=5,04$ хв.; $\mathrm{n}_{\mathrm{N}}=9,855$ об/хв. (випромінювач на YAG: $\mathrm{Nd}^{+3}$ ЛTI-502).

3. Технологічне обладнання та оснащення операцій лазерного очищення

Для реалізації наведених технологічних схем лазерного очищення форм від залишків фарби та іншого бруду лту повинна мати такий склад: (рис. 4).

Особливістю складу лту є наявність можливості змінення лазера (з відповідними блоками живлення та охолодження):
- при очищенні форм із металу та кераміки (анілоксові) бажано використовувати лазер на $\mathrm{CO}_{2}$ типу ЛГІ-50-3 (поз. 1*, рис. 5);

- неметалеві форми з гуми, поліуретану, капрону, графітвінілпласту пластмаси та багатошарові форми рекомендовано очищувати випромінюванням 3 довжиною хвилі $\lambda=1,06$ мкм лазер ЛТІ-502 (поз. 1);

Для зменшення об'єму робіт з переналагодження ЛТУ при заміні лазера необхідно передбачити:

- застосування поворотних та похилих дзеркал із міді (поз. 4 і 16, рис. 5);

- прозорі оптичні елементи, які перетворюють робочий промінь (лінзи, плоско-паралельні пластинки, оптичні клини, тощо) повинні бути виготов-

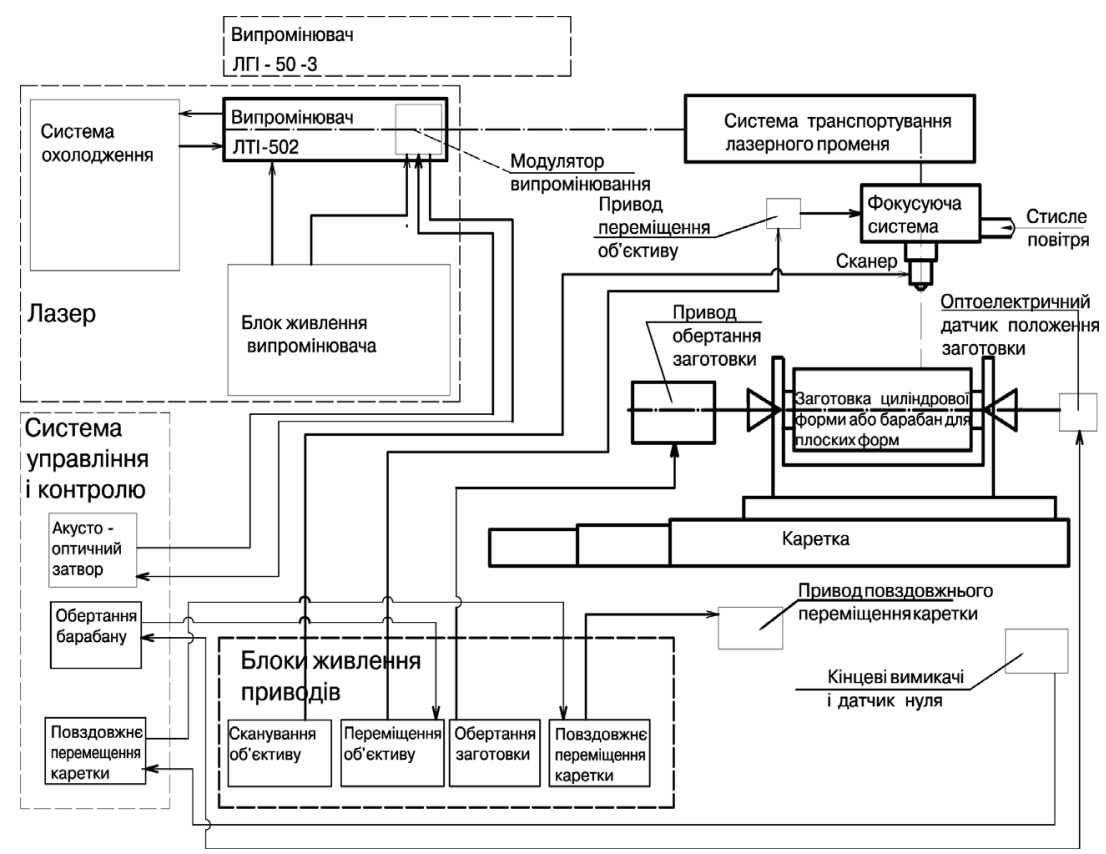

Рис. 4. Блок-схема лту для лазерного очищення робочої поверхні друкарських форм 


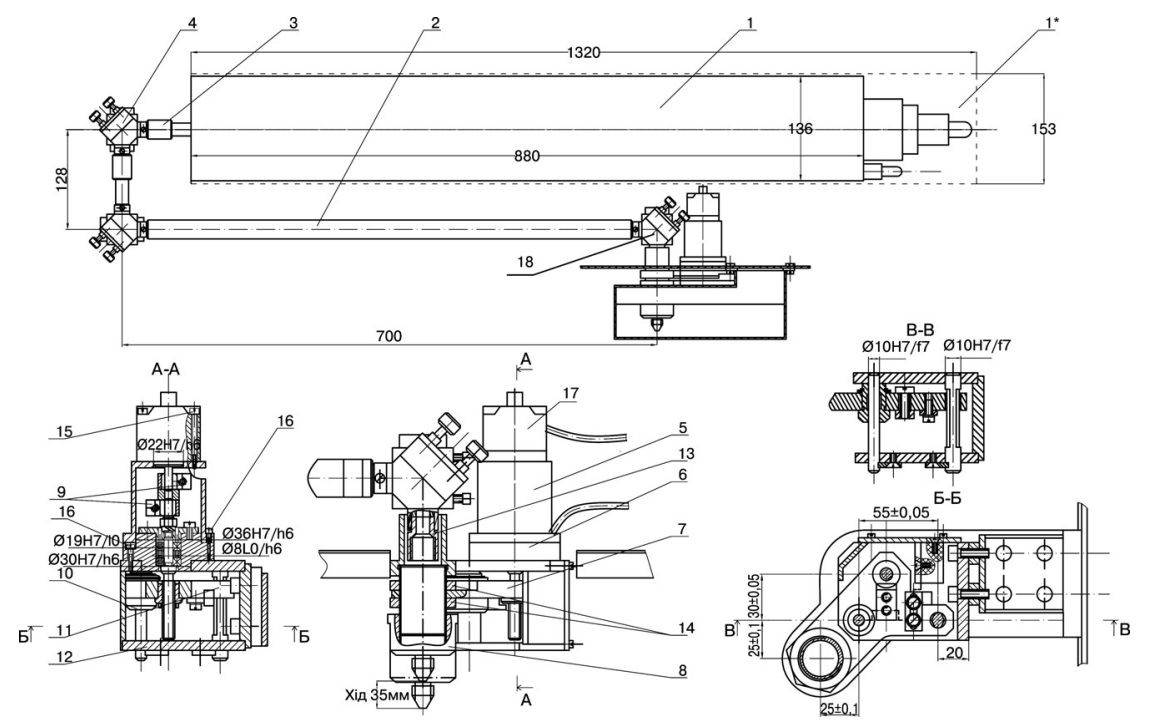

Рис. 5. Оптична система лту

леними 3 інфрачервоних матеріалів, прозорих у видимій частини спектру, наприклад із SeZn, або необхідно мати відповідні їх набори для двох видів випромінювання.

Елементи ЛтУ, що рухаються, мають керуємі приводи на крокових двигунах ДШІ-200 (ДШ200), з мотор-редуктором МЗК3 та на електромагнітах (рис. 6) для частотних коливань дзеркал резонатора в модуляторі та сканера.

На рис. 7 зображено компоновку Лту (вид зверху). Ї̈̈ особливістю є надання робочих переміщень каретці 13 - поступове та формі 15 (барабану) обертальне. За такою схемою гарантуються незмінні значення кутових та розмірних характеристик пучка випромінювання в оптичній системі 10, тобто розмір зони опромінення вздовж поверхні друкарської форми 15.
Для надання можливості реалізації розрахункових режимів обробки для різних технологічних операцій (видалення залишків різноманітних фарб 3 комірок друкарських форм, виготовлених із металів та неметалів) складові серійних ЛТУ необхідно оснастити додатковими елементами та пристроями, 3окрема, для розширення енергетичних та часових можливостей випромінювача на YAG: $\mathrm{Nd}^{+3}$ ЛТІ502 (параметрів модуляції випромінювання) та сканування пучка випромінювання поперек кругової подачі $\mathrm{V}_{\text {об. }}$.

Модулятор багатомодового пучка випромінювання

Для створення імпульсного режиму генерації випромінювача ЛТІ-502 при безперервному накачуванні його активного середовища використовується періодична модуляція добротності резонатора акустооптичним затвором шляхом відхилен- 


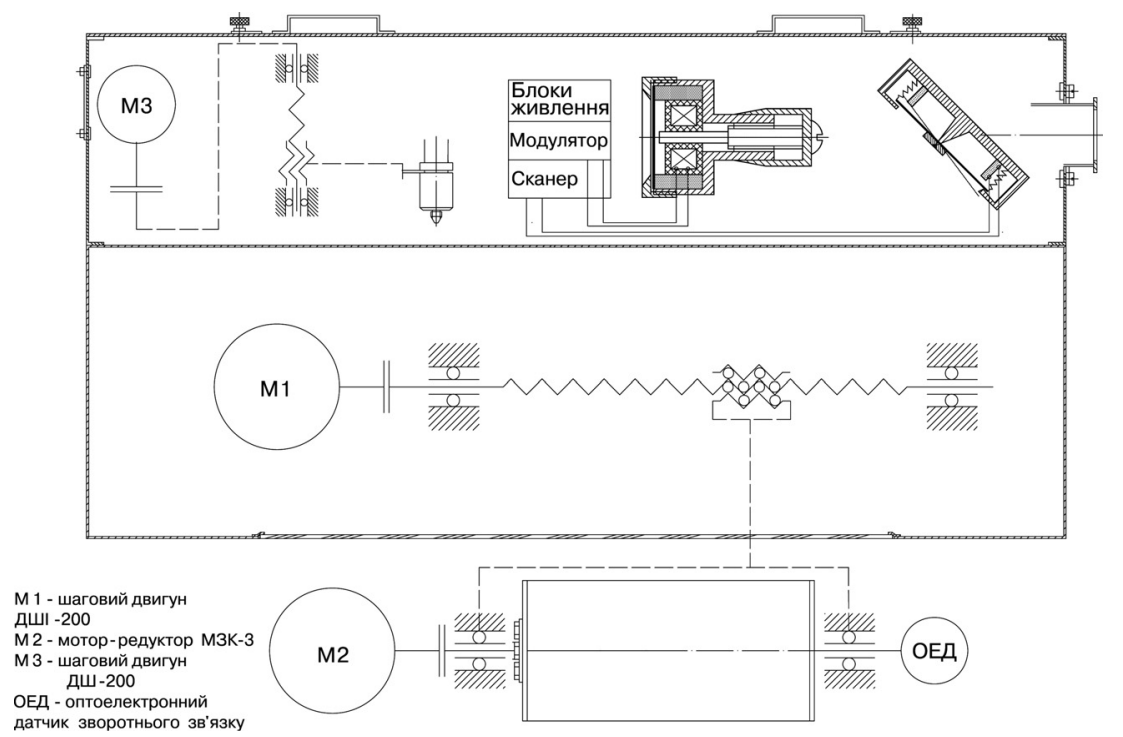

Рис. 6. Кінематична схема та приводи лту

ня пучка випромінювання від осі резонатора на дифракційній решітці, яку створено акустичною хвилею. В зв'язку з тим, що кут відхилення променя визначається його довжиною хвилі, то 100 \% модуляція пучка випромінювання можлива лише в разі його структури $\mathrm{TEM}_{00}$, що досягається обмеженням попереку активного елементу 3 $\varnothing 6,5$ мм до 2 мм і відповідним зменшенням середньої потужності випромінювання 3 32 Вт до 8.

Для 100 \% модуляції пучків випромінювання TEM $_{\mathrm{mn}}$ рекомендується резонатор із пов-

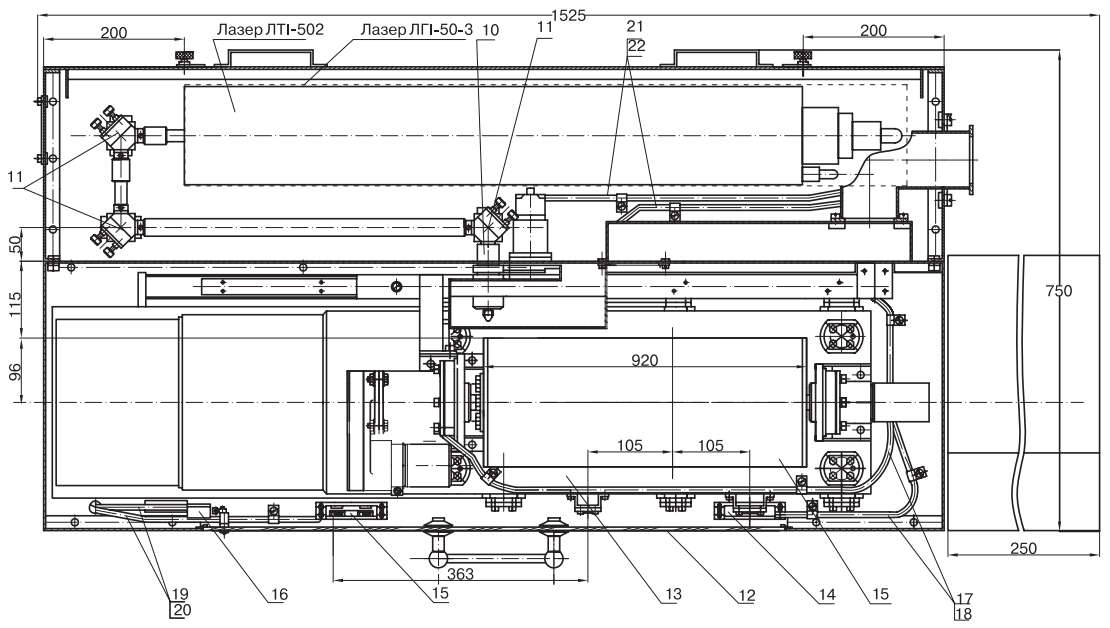

Рис. 7. Компоновка ЛтУ для лазерного очищення форм із змінними випромінювачами 


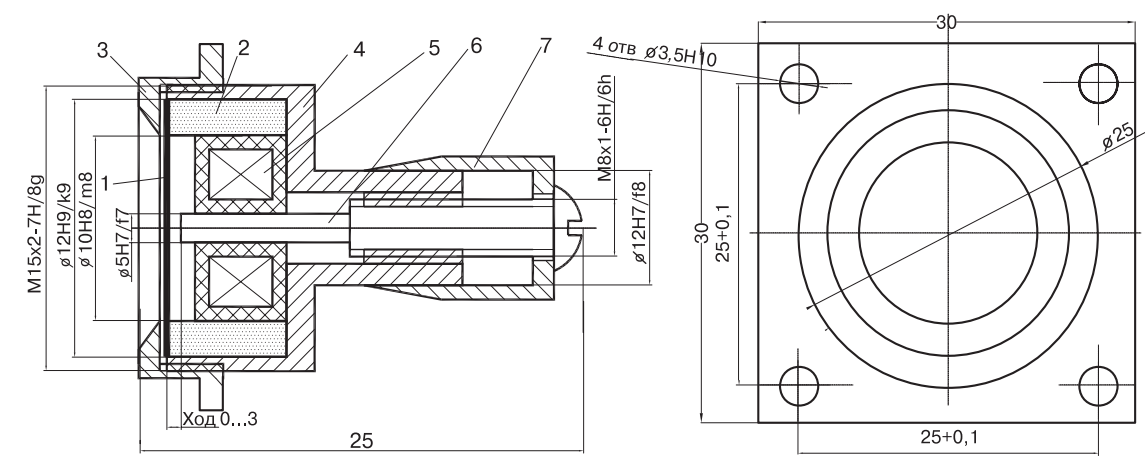

Рис. 8. Конструкція 100 \% дзеркала-модулятора (1 - гнучке дзеркало, 2 - постійний магніт, 3 - кришка, 4 - корпус, 5 - електромагніт, 6 - сердечник електромагніту, 7 - лімб)

ністю відбивальним дзеркалом у вигляді мембрани [9], конструкція якого зображена на рис. 8, а загальний вид - на рис. 9.

Якісні дані застосування модулятора наведено в [5] на рис. 2.32 та 2.33.

Сканер для лінійного сканування лазерного променя

Для операцій із додатковим швидкісним скануванням променя впоперек обертової подачі форми з метою розширення зони опромінення (очищення) її поверхні та зменшення швидкості обертання заготовки в оптичному вузлі 18 (рис. 5) замість

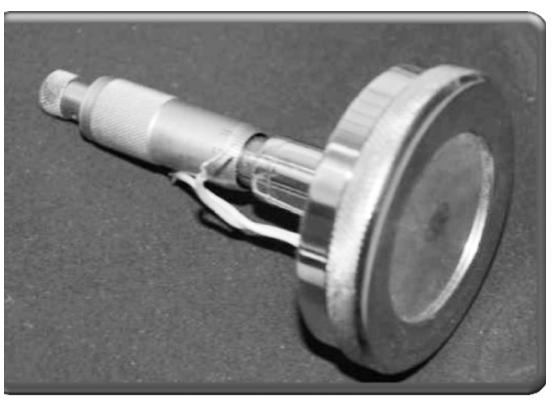

Рис. 9. Загальний вигляд дзеркала-модулятора поворотного дзеркала встановлюється вузол сканування на похилому дзеркалі із міді 3 (рис. 10 [9]). Особливістю його конструкції $€$ обмеження гармонічного закону сканування променя (залежність 9 на рис. 10, б) за вільного коливання коромисла 4 відносно осі 2 під дією знакозмінних полів електромагнітів 6, живлення яких зміщено за фазою на $\pi^{\circ}$. Це обмеження надають два упори 8, що утворюють зазори $\Delta$ з коромислом: $\Delta=\operatorname{atg}\{0,5 \operatorname{arctg}[\mathrm{A} /(2 \mathrm{~F})]\}$ (де а радіус розташування упорів; A - розмах коливань; F - фокусна відстань лінзи). За участю пружин 5, розташованих на периферіях коромисла 4, формується швидкий відрив коромислу від відповідного упору 8, що забезпечує пилкоподібний закон переміщення 10 (рис. 10, б) променя 3 постійною швидкістю його руху $\mathrm{V}_{\mathrm{cк}}$ по поверхні форми. Для наведеного прикладу при $\mathrm{A}=$ $=10 \mathrm{~mm}, \mathrm{a}=20 \mathrm{~mm}, \mathrm{~F}=50 \mathrm{~mm}$ $\Delta=0,9975$ мм. 

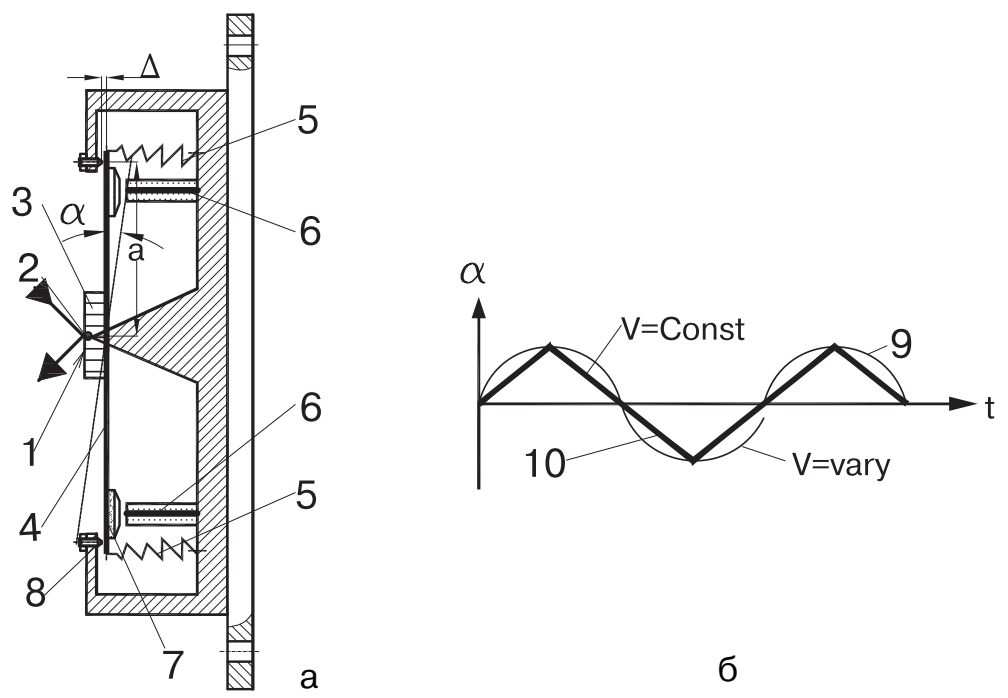

б

Рис. 10. Схема сканера (а) та закону сканування променя (б): 1 - дзеркальна поверхня; . 2 - вісь коливання дзеркала; 3 - дзеркало; 4 - коромисло; 5 - пружини; 6 - електромагніти; 7 - п'ята́; 8 - упор; 9 - гармонічна та 10 - пилкоподібна залежності

\section{Висновки}

1. Більшість операцій очищення поверхонь виробів загального машинобудування та приладобудування, які відносяться до підготовчого циклу процесу їх виготовлення, не можуть бути застосовані у відомому вигляді для видалення залишків фарби з робочих елементів друкарських форм.

2. Особливості застосування лазерного променя в операціях очищення друкарських форм пов'язані 3 необхідністю організації визначеного та різного характеру поверхневого та лінійного поглинання випромінювання матеріалами бруду та елементів друкарських форм.

3. Незалежно від обраного механізму руйнування контакту між поверхнею форми та брудом (випаровуванням останнього або термомеханічним його відокремленням та видален- ням) бажано використовувати таке сполучення хвильових властивостей лазерного променя та матеріалів форми та бруду, щоб виключити або обмежити, принаймні, участь теплопровідності в руйнуванні бруду та поверхні заготовки.

4. Для різнорідних матеріалів бруду (фарби) та форми, наприклад, для металевих форм оптимальним $€$ використання випромінювання 3 високим рівнем поверхневого (А) та об'ємним $(\alpha)$ поглинанням у фарбі та низьким і поверхневим - в металі. В разі виготовлення форми із неметалів ця вимога майже не досяжна, тому головним аргументом в організації вибіркового поглинання може стати тривалість опромінення (тривалість імпульсу випромінювання $\tau$ ) 3 використанням кількох імпульсів для повного очищення комірок форми. 
5. В разі відсутності промислового обладнання для виконання операції очищення форм в наведених вище умовах треба використати можливості модернізації його складових, а також додаткового технологічного оснащення.

1. Лазерная очистка в машиностроении и приборостроении / В. П. Вейко, В. Н. Смирнов, А. М. Чирков и др. - СПб : НИУ ИТМО, 2013. - 103 с. 2. Грилихес С. Я. Обезжиривание, травление и полирование металлов. Л. : Машиностроение, 1983. - 101 с. 3. Вейко В. П. Физические механизмы лазерной очистки поверхности / В. П. Вейко, Е. Ф. Шахно // Известия РАН, сер. Физическая. - 2001. - т. 65. - № 4. - С. 584-587. 4. Котляров В. П. Лазерна технологія в поліграфії / В. П. Котляров, П. О. Киричок. Київ : НТУУ «КПІ» ВПК «Політехніка». - 2012. - 324 с. 5. Котляров В. П. Технологічне оснащення лазерних комплексів / В. П. Котляров. - Підручник. - Київ : НТУУ «КПІ» ВПК «Політехніка». - 2013. - 592 с. 6. Котляров В. П. Технологія лазерної обробки (операції розмірної обробки) / В. П. Котляров. - Підручник. - Ніжин : НДУ ім. М. Гоголя, 2010. - 308 с. 7. Siano S. Лазерная очистка позолоченных бронзовых и медных поверхностей / S. Siano, B. А. Парфенов // Материалы научной конференции «Реставрация, консервация и музеефикация исторических крепостей», (2-4 октября 2013 г.). 8. Самохвалов А. Технология глубокой лазерной очистки анилоксовых валов / А. Самохвалов, М. Ярчук // Флексо Плюс. - 2010. № 6. - С. 42-46. 9. Андріяхін В. М., Бабицький В. І., Майоров В. С., А. с. CPCP № 1042468, G02B 26/10. Сканатор для лазерної технологічної установки. Опубл. 20.03.1988, бюл. № 12.

1. Lazernaja ochistka $v$ mashinostroenii i priborostroenii / V. P. Vejko, V. N. Smirnov, A. M. Chirkov i dr. - SPb : NIU ITMO, 2013. - 103 s. 2. Grilihes S. Ja. Obezzhirivanie, travlenie i polirovanie metallov. - L. : Mashinostroenie, 1983. - 101 s. 3. Vejko V. P. Fizicheskie mehanizmy lazernoj ochistki poverhnosti / V. P. Vejko, E. F. Shahno // Izvestija RAN, ser. Fizicheskaja. 2001. - t. 65. - № 4. - S. 584-587. 4. Kotliarov V. P. Lazerna tekhnolohiia v polihrafii / V. P. Kotliarov, P. O. Kyrychok. - Kyiv : NTUU «KPI» VPK «Politekhnika». - 2012. - 324 s. 5. Kotliarov V. P. Tekhnolohichne osnashchennia lazernykh kompleksiv / V. P. Kotliarov. - Pidruchnyk. - Kyiv : NTUU «KPI» VPK «Politekhnika». - 2013. - 592 s. 6. Kotliarov V. P. Tekhnolohiia lazernoi obrobky (operatsii rozmirnoi obrobky) / V. P. Kotliarov. - Pidruchnyk. - Nizhyn : NDU im. M. Hoholia, 2010. - 308 s. 7. Siano S. Lazernaja ochistka pozolochennyh bronzovyh i mednyh poverhnostej / S. Siano, V. A. Parfenov // Materialy nauchnoj konferencii «Restavracija, konservacija i muzeefikacija istoricheskih krepostej», (2-4 oktjabrja 2013 g.). 8. Samohvalov A. Tehnologija glubokoj lazernoj ochistki aniloksovyh valov / A. Samohvalov, M. Jarchuk // Flekso Pljus. - 2010. - № 6. - S. 42-46. 9. Andriiakhin V. M., Babytskyi V. I., Maiorov V. S., A. s. SRSR № 1042468, G02V 26/10. Skanator dlia lazernoi tekhnolohichnoi ustanovky. Opubl. 20.03.1988, biul. № 12.

Рецензент - А. І. Жученко, д.т.н., професор, НТУУ «КП।»

Надійшла до редакції 21.11.13 